\title{
Decision Support System for Determining Employee Working Time with Analytical Hierarchy Process Method
}

Essther Ika Chardina

Jurusan Pendidikan, Program Studi Teknik Informatika, Universitas Sanata Dharma, Indonesia

\section{Article Info}

\section{Article history:}

Received: 05/01/2021

Revised: 22/02/2021

Accepted: 01/03/2021

Available online 30/03/2021

\section{Keywords:}

AHP Method,

DSS,

Employee Working Time

\begin{abstract}
Operational work of a company can not be separated from the placement of employee work time. The placement of employees in accordance with their achievements and abilities at the right working time supports the smooth operation of the company's work. In this final project, a decision support system for determining the working time of employees is made by using the Analytical Hierarchy Process (AHP) method. The Analytical Hierarchy Process method is an approach method used to help solve problems that require values based on existing considerations into an easier and structured process. This method is expected to help operational managers in determining the working time of employees.
\end{abstract}

This is an open access article under the CC BY-NC license.

\section{Corresponding Author:}

Essther Ika Chardina, Jurusan Pendidikan,

Program Studi Teknik Informatika,

Universitas Sanata Dharma, Indonesia,

Jl. Afandi, Sleman, Yogyakarta, Indonesia.

Email: chardina.essther@gmail.com

\section{Introduction}

Decision making in solving a problem, both simple and complex problems are always faced with alternative solutions to solve optimal problems, in solving the required problems, problems faced quickly and precisely without limitations (Sirait, 2019) (Silitonga, 2016).

As in the process of determining the working time of employees at Teammates Coffee Indonesia (TMCI), it must be done as well as possible by taking into account the influencing factors in order to produce the right decision, the operational manager plays an important role in determining the working time of employees, therefore the operational manager must be able to regulate and determine employee working time quickly and precisely and in accordance with company operational standards.

The working time of employees at the TMCI company still uses a manual and random system so that the results obtained are still not good, with a system like this it often results in the placement of employees on an inaccurate schedule.

\section{Method}

The method used to solve the problem of determining employee working time is the System Development Life Cycle method (Waterfall Paradigm). In this method consists of stages: requirements analysis, system design, coding, and testing.

a. Needs Analysis

In this case identify and analyze the needs of all system elements by collecting data. 


\section{b. System planning}

The design/design stage is the stage of translating the requirements/needs into a software representation that can be estimated. This design process includes system design, database design, user interface design and program design.

c. $\quad$ Coding

In this case the coding stage is the stage of translating the design results using a particular programming language.

d. Test

In this case the program testing phase is carried out to find errors by executing the program.

e. Research sites

In this case, the location of the research was conducted at PT. TMCI (Teammates Coffee Indonesia) Jalan Bougenville 1, Yogyakarta, Indonesia

\subsection{AHP Method Analysis}

Analisis data menerapkan metode Analytical Hierarchical Process (AHP), yang memungkinkan perhitungan matematis dengan berbagai kriteria (Umar, Fadlil, \& Yuminah, 2018). Analytic Hierarchy Process (AHP) merupakan metode yang dapat menyelesaikan masalah pengambilan keputusan berdasarkan banyak kategori (Sasongko, Astuti, \& Maharani, 2017).

The basic principles of solving AHP problems are as follows:

a. Decomposition.

Decomposition needs to be done after the problem is defined. Decomposition divides a whole problem into elements that cannot be further divided. This analysis process is referred to as a hierarchy (Rahmanita, Prastiti, \& Jazari, 2018) (Sa'adati, Fadli, \& Imtihan, 2018).

b. Comparative Judgment (Comparative Judgment). Make an assessment of a certain level related to the level above it. The form of the pairwise comparison matrix makes it easier to present the assessment (Diana \& Utari, 2017) (Sodiqin, 2019).

c. Synthesis of Priority Global priorities are obtained by synthesizing among local priorities. Local priority is obtained from the Pairwise Comparison matrix at each level. Each synthesis has a different procedure. The best value scale in expressing opinions is 1 to 9 scale - the values and definitions of each scale are shown in (Saaty \& Shang, 1996).

d. Logical Consistency There are two meanings of consistency, namely: grouping similar objects according to their uniformity and relevance, and the level of relationship object according to criteria (Abiyoga, Sulistyo, \& Widyastuti, 2018).

\section{Results and Discussion}

\subsection{Results}

From the problem of determining the working time of employees, several samples of employees are taken which will be processed and then placed on a work time or shift schedule that is in accordance with the provisions.

In determining the working time of this employee, the following stages will be carried out:

Priority determination of days and shifts, in determining the priority of days, with the aim of determining the priority of working days for employees who need special considerations. This special consideration will indirectly affect the user in making decisions to determine the appropriate and appropriate choice of employees. Where in determining priorities the user does it directly on the input menu. Likewise, the determination of shift priority is carried out to get the main priority of the employee's working time every day. In this case, several alternative working hours of employees are determined which consist of shift opening, shift middle, and then shift closing.

Determination of employees in this employee determination, is to select employees with appropriate criteria, with the aim of obtaining sequential priorities for each employee based on a comparison of criteria with levels consisting of criteria and employee levels. Some of the system rules that apply in determining the working time of this employee are,

employees are not allowed to request shifts, each employee is required to have at least one shift, employees are not allowed to continue shifts in one day, the number of employee needs in one day 
must not exceed and equal the number of available employees, quota for each shift every day inlimit it according to need, if the shift quota has been met and there are still employees who have not received a shift, they will enter the next day, according to the shift quota on the next day, and with consideration based on the results of calculations and the level of importance of the shift in each day which is determined manually. by users.

In determining the selected employees, this is done by applying the AHP method. Based on the number of criteria and the number of employees that will have been inputted by the user, the system will form a matrix which will be processed to obtain employee data sequentially according to the priority specified by the user.

\section{a. Steps to Set Priorities}

In this second step, the priority of the elements is set by setting preference interests by forming a matrix to compare the assessment criteria in pairs and then adding up each column.

TABLES 1.

CRITERIA COLUMN SUM MATRIX

\begin{tabular}{ccccc}
\hline Criteria & $\begin{array}{c}\text { Length of } \\
\text { working }\end{array}$ & SOUP & Attendance & Performance \\
\hline Length of working & 1 & 2 & 5 & 3 \\
SOUP & 0.5 & 1 & 3 & 4 \\
Attendance & 0.2 & 0.33 & 1 & 2 \\
Performance & 0.33 & 0.25 & 0.5 & 1 \\
\hline \& column & $\mathbf{2 . 0 3}$ & $\mathbf{3 . 5 8}$ & $\mathbf{9 . 5}$ & $\mathbf{1 0}$ \\
\hline
\end{tabular}

Then divide the input value by the sum of each corresponding column, then add up each row.

TABLE 2.

CRITERIA ROW SUM MATRIX

\begin{tabular}{llllll}
\hline Criteria & \multicolumn{5}{c}{ CRITERIA ROW SUM MATRIX } \\
& $\begin{array}{l}\text { Length of } \\
\text { working }\end{array}$ & Attendance & SOUP & Performance & ₹Line \\
\hline Length of working & $1 / 2.03$ & $2 / 3.58$ & $5 / 9.5$ & $3 / 10$ & 1.88 \\
Attendance & $0.5 / 2.03$ & $1 / 3.58$ & $3 / 9.5$ & $4 / 10$ & 1.24 \\
SOUP & $0.2 / 2.03$ & $0.33 / 3.58$ & $1 / 9.5$ & $2 / 10$ & 0.50 \\
Performance & $0.33 / 2.03$ & $0.25 / 3.58$ & $0.5 / 9.5$ & $1 / 10$ & 0.39 \\
\hline
\end{tabular}

To get a priority vector for each criterion, the number of rows is divided by the number of criteria, in this case study the criteria in question are 4 elements, so that the number of rows is divided by 4 criteria.

TABLE 3.

CRITERIA RESULT DIVISION MATRIX

\begin{tabular}{ll}
\hline Criteria & priority vector \\
\hline Length of working & 0.4691 \\
SOUP & 0.3102 \\
Attendance & 0.1242 \\
Performance & 0.0966 \\
\hline
\end{tabular}

\section{b. Determining Employee Shift Priorities}

To determine the priority of employee shifts is to determine the order of priority through input in the shift data input form. The following is an example of a shift priority table defined by a user:

TABLE 4.

SHIFT PRIORITY TABLE

\begin{tabular}{llll}
\multicolumn{3}{c}{ ShIFT PRIORITY TABLE } \\
\hline 1 & Shift name & Day & Number of employees \\
2 & Closing & art & 2 \\
3 & Middle & Monday & 1 \\
\hline
\end{tabular}

\subsection{Discussion}

In the last process, is to determine employee shifts according to existing priorities. Employees who have the highest priority vector value will get a shift with the highest priority value which has 
been determined by the user in advance when inputting shift data, for example in table 4 above. Then after combining the results will be as follows,

TABLE 5.

EMPLOYEE WORKING TIME

\begin{tabular}{llr}
\hline Day & Shift & Employee name \\
\hline Monday & Closing & Ika Renata \\
Monday & Closing & Isabela \\
Monday & Middle & Rihana \\
Monday & Opening & Edward C \\
\hline
\end{tabular}

\section{Conclusion}

Through the results of the SPPK program for determining employee working time, using the AHP method, the authors conclude that the AHP method can help solve complex employee working time determination problems. This AHP method is not suitable for use when the number of input criteria and alternatives is on a large scale. Qualitative calculations are less efficient in completing the determination of employee working time

\section{Reference}

Abiyoga, R., Sulistyo, B., \& Widyastuti, L. (2018). Perancangan Bobot Kriteria Jabatan Manajer Senior Pengelolaan Sumber Daya Manusia Di Divisi Sumber Daya Manusia Menggunakan Metode Analytical Hierarcy Process Di Pt. xyz. EProceedings of Engineering, 5(3).

Diana, A., \& Utari, D. R. (2017). Penerapan Metode Analytical Hierarchy Process (AHP) dalam Sistem Penunjang Keputusan Pemilihan Vendor Desain Grafis. Telematika MKOM, 8(2), 97-106.

Rahmanita, E., Prastiti, N., \& Jazari, I. (2018). Penggunaan Metode AHP dan FAHP dalam Pengukuran Kualitas Keamanan Website E-Commerce. Jurnal Teknologi Informasi Dan Ilmu Komputer, 5(3), 371-380.

Sa'adati, Y., Fadli, S., \& Imtihan, K. (2018). Analisis Penggunaan Metode AHP dan MOORA untuk Menentukan Guru Berprestasi sebagai Ajang Promosi Jabatan. Sinkron: Jurnal Dan Penelitian Teknik Informatika, 3(1), 82-90.

Saaty, T. L., \& Shang, J. S. (1996). The analytic hierarchy process and the voting system. Proceedings of the Fourth International Symposium on the Analytic Hierarchy Process. Simon Fraser University, Burnaby, BC, Canada, 505-517.

Sasongko, A., Astuti, I. F., \& Maharani, S. (2017). Pemilihan Karyawan Baru Dengan Metode AHP (Analytic Hierarchy Process).

Silitonga, D. S. (2016). PERANAN AKUNTANSI MANAJEMEN DALAM PROSES PENGAMBILAN KEPUTUSAN PADA PT. PEGADAIAN (PERSERO) KANTOR WILAYAH 1 MEDAN.

Sirait, D. R. (2019). PERANAN AKUNTANSI MANAJEMEN DALAM PENGAMBILAN KEPUTUSAN PADA PT PERUSAHAAN LISTRIK NEGARA (PERSERO) UNIT PELAYANAN TRANSMISI PEMATANG SIANTAR.

Sodiqin, M. (2019). Sistem Pendukung Keputusan Pemilihan Merek CCTV Menggunakan Metode Analytical Hierarchy Process Pada PT. Panca Pastika Mandiri Jakarta.

Umar, R., Fadlil, A., \& Yuminah, Y. (2018). Sistem Pendukung Keputusan dengan Metode AHP untuk Penilaian Kompetensi Soft Skill Karyawan. Khazanah Informatika: Jurnal Ilmu Komputer Dan Informatika, 4(1), 27-34. 